\title{
Memória operacional fonológica e compreensão de orações em crianças com desenvolvimento típico de linguagem entre 3:0 e 6:11 anos
}

\author{
Amalia Rodrigues
}

Rodrigues A. Memória operacional fonológica e compreensão de orações em crianças com desenvolvimento típico de linguagem entre 3:0 e 6:11 anos [tese]. São Paulo: Universidade de São Paulo; 2007.

A memória fonológica possui relação com muitas habilidades de linguagem como, a aquisição vocabular, a compreensão da linguagem, o processamento sintático e a compreensão de leitura. A presente pesquisa teve como objetivo investigar a relação entre a memória operacional fonológica e a compreensão de orações a partir de três estudos. Os sujeitos foram 136 crianças em desenvolvimento típico de linguagem, falantes do Português do Brasil, com idade entre 3:0 e 6:11 anos. O primeiro estudo avaliou a memória operacional fonológica a partir de um teste de repetição de não-palavras, que variavam em extensão, entre uma e quatro sílabas. Os resultados indicaram que houve melhora no desempenho de repetição de não-palavras com o avanço da idade e efeito de extensão com o aumento do número de sílabas. Também foi verificada a correlação entre idade, Porcentagem de Consoantes Corretas-Revisada (PCC-R) e memória fonológica. As tipologias de erros de maior ocorrência no grupo total foram troca e contaminação de fonemas. No segundo estudo, verificou-se a compreensão de orações, nãoredundantes e redundantes, em quatro estruturas frasais a partir de um teste de identificação de figuras. Observaramse efeitos de complexidade sintática e de extensão nas quatro partes do teste. $\mathrm{O}$ acréscimo de redundância dificultou a compreensão de todas as orações, exceto as sentenças com dupla marcação de número nas idades de cinco e seis anos. Houve correlação significativa entre a idade, o vocabulário expressivo e a compreensão de orações. No terceiro estudo, foi investigada a correlação entre a memória operacional fonológica e a compreensão de orações. Os resultados demonstraram que as crianças foram melhores no teste de repetição de não-palavras do que no teste de compreensão de orações. Houve correlação moderada entre a memória operacional fonológica e a compreensão de orações para o grupo total de sujeitos. 